\title{
Nuclear SMAD2 Restrains Proliferation of Glioblastoma
}

\author{
Yunhu Yua,b Qishan Rana,b \\ aDepartment of Neurosurgery, the First People's Hospital of ZunYi, bDepartment of Neurosurgery, the \\ Third Affiliated Hospital, ZunYi Medical College, ZunYi, China
}

\section{Key Words}

Glioblastoma multiforme (GBM) - Transforming growth factor $\beta$ (TGF $\beta) \cdot S M A D 2$ - SMAD3 • p21 - Cancer cell growth

\begin{abstract}
Aims: Although TGF $\beta$ receptor signaling has been shown to play a role in regulation of the growth and metastasis of glioblastoma multiforme (GBM), the downstream pathway through either SMAD2 or SMAD3 has not been elucidated. In this study, we investigate whether nuclear SMAD2 can restrain the proliferation of glioblastoma. Methods: A total of 23 resected specimens from GBM patients were collected for SMAD2 detection. Human GBM cell line A172, U87mg, D341m and Hs683 were maintained in Dulbecco's modified Eagle's medium and transfected with SMAD2 and SMAD3 shRNA plasmids. Gene expression was detected by RTqPCR and Western and cell growth were detected by MTT assay. Results: Our results showed that the phosphorylated SMAD2 (pSMAD2, the nuclear and functional form of SMAD2) levels in GBM were significantly lower than the paired normal brain tissue in patients. Depletion of SMAD2, but not SMAD3, significantly abolished the inhibitory effects of TGF $\beta 1$ on the growth of GBM cells, possibly through pSMAD2-mediated increases in cell-cycle inhibitor, p27. Conclusion: Our data suggest that TGF $\beta / S M A D 2$ signaling cascades restrains growth of GBM.
\end{abstract}

Copyright (C) 2015 S. Karger AG, Basel

\section{Introduction}

Glioblastoma multiforme (GBM), which is named as glioblastoma by WHO, is the most common and most malignant primary brain cancer in humans [1-5]. GBM is originated from glial cells and the patients suffer from an extremely low five-year survival ratio, which reasons from the relatively high invasiveness of GBM and the location of the tumor in the relatively 
closed central nervous system [1-5]. Hence, understanding of the molecular control of the growth of GBM represents one of the most important questions in the research in GBM, in which it may provide innovative therapy for the disease.

Transforming Growth Factor $\beta$ (TGF $\beta$ ) receptor signaling pathways play essential and diverse roles in the regulation of many biological events, including cell replication, differentiation, apoptosis, epithelial-mesenchymal transition, and tissue remodeling [6-12]. Binding of a TGF $\beta$ ligand $(1,2$ or 3$)$ to a type II TGF $\beta$ receptor induces the phosphorylation of a type I TGF $\beta$ receptor, which subsequently phosphorylates receptor-regulated SMADs proteins (SMAD2 and SMAD3). Phosphorylated SMAD2 or SMAD3 then forms heteromeric complexes with the common-mediator SMAD (SMAD4) to be translocated into the nucleus [6-12], where they regulate the gene transcription, e.g. activation of p21 [13-18] and p27 $[12,19-21]$. Although TGF $\beta$ receptor signaling pathway has been extensively studied and is suggested to play a critical role in controlling growth and invasion of GBM [22-38], the signaling pathway through SMAD2 or SMAD3 has not been distinguished yet.

Here, we showed that the phosphorylated SMAD2 (pSMAD2, the nuclear and functional form of SMAD2) levels in GBM were significantly lower than the paired normal brain tissue in patients. Depletion of SMAD2, but not SMAD3, significantly abolished the inhibitory effects of TGF $\beta 1$ on the growth of GBM cells, possibly through pSMAD2-mediated increases in cellcycle inhibitor, p27.

\section{Materials and Methods}

\section{Patient tissue specimens}

A total of 23 resected specimens from GBM patients were collected for this study. All specimens had been histologically and clinically diagnosed at Department of Neurosurgery of the First People's Hospital of ZunYi from 2007 to 2013. For the use of these clinical materials for research purposes, prior patient's consents and approval from the Institutional Research Ethics Committee were obtained.

\section{Cell line culture and transfection}

Human GBM cell line A172 (GBM) [39], U87mg (GBM/astrocytoma) [40], D341m (medullomyoblastoma) [41] and Hs683 (Glioma) [41] have been described before and were used in the current study. Since similar results were achieved from these cell lines, only data from A172 cells were shown. These cell lines were maintained in Dulbecco's modified Eagle's medium (DMEM, Invitrogen, Carlsbad, CA, USA) supplemented with $10 \%$ fetal bovine serum (PAA, Austria). SMAD2 and SMAD3 shRNA plasmids (sc-38374SH and sc-38376-SH) were purchased from Santa Cruz (St Jose, CA, USA). Transfection was performed with Lipofectamine 2000 reagent (Invitrogen), according to the instructions of the manufacturer. SB431542 [4244] was purchased from Sigma-Aldrich (St Louis, MO, USA), and used at a dose of $10 \mu \mathrm{mol} / \mathrm{l}$.

\section{RNA extraction, reverse transcription and RT-qPCR}

Total RNA was extracted from the cultured cells using RNeasy kit (Invitrogen), according to the manufacturer's instruction. For mRNA analysis, complementary DNA (cDNA) was randomly primed from $2 \mu \mathrm{g}$ of total RNA using the Omniscript reverse transcription kit (Qiagen, Hilden, Germany). Real-time quantitative PCR (RT-qPCR) was subsequently performed in triplicate with a 1:4 dilution of cDNA using the Quantitect SyBr green PCR system (Qiagen) on a Rotorgene 6000 series PCR machine. All primers were purchased from Qiagen. Data were collected and analyzed using the Rotorgene software accompanying the PCR machine. Relative expression levels were determined using the comparative quantification feature of the Rotorgene software. All mRNA quantification data were normalized to $\alpha$-tubulin, and then compared to controls.

\section{Western blot}

Protein was extracted from the cultured cells by RIPA buffer (Sigma-Aldrich) for Western Blot. The supernatants were collected after centrifugation at $12000 \times \mathrm{g}$ at $4^{\circ} \mathrm{C}$ for $20 \mathrm{~min}$. Protein concentration was determined using a BCA protein assay kit (Bio-rad, China), and whole lysates were mixed with $4 \times$ SDS 
loading buffer (125 mmol/l Tris-HCl, 4\% SDS, 20\% glycerol, $100 \mathrm{mmol} / \mathrm{l}$ Dithiothreitol (DTT), and 0.2\% bromophenol blue) at a ratio of 1:3. Samples were heated at $100^{\circ} \mathrm{C}$ for $5 \mathrm{~min}$ and were separated on SDSpolyacrylamide gels. The separated proteins were then transferred to a PVDF membrane. The membrane blots were first probed with a primary antibody. After incubation with horseradish peroxidase-conjugated second antibody, autoradiograms were prepared using the enhanced chemiluminescent system to visualize the protein antigen. The signals were recorded using X-ray film. Primary antibodies for Western Blot are anti-human SMAD3, phosphorylated-SMAD3 (pSMAD3), SMAD2, phosphorylated SMAD2 (pSMAD2), p27 and $\alpha$-tubulin (Cell Signaling, St Jose, LA, USA). Secondary antibody is HRP-conjugated anti-rabbit (Jackson Labs, LA, USA). Secondary antibody is HRP-conjugated anti-rabbit (Jackson Labs, Bar Harbor, ME, USA). Images shown in the figure were representative from 5 repeats. Densitometry of Western blots was quantified with NIH ImageJ software.

\section{MTT assay}

For assay of cell growth, the cells were seeded into 96 well-plate at 4000 cells per well and subjected to a MTT kit (Roche, Indianapolis, IN, USA), according to the manufacturer's instruction. The MTT assay is a colorimetric assay for assessing viable cell number, since $\mathrm{NAD}(\mathrm{P}) \mathrm{H}$-dependent cellular oxidoreductase enzymes in viable cells are capable of reducing the tetrazolium dye MTT 3-(4,5-dimethylthiazol-2-yl)-2,5diphenyltetrazolium bromide to its insoluble formazan, which is in purple color and could be quantified.

\section{Statistical analysis}

Each experiment condition contains 5 repeats. All values are depicted as mean \pm standard deviation and are considered significant if $\mathrm{p}<0.05$. All data were statistically analyzed using one-way ANOVA with a Bonferoni correction.

\section{Results}

Lower phosphorylated SMAD2 was detected in GBM, compared to paired normal brain tissue in patients

Since TGF $\beta$ receptor signaling has been shown to play a critical role in controlling growth and invasion of GBM but the levels of the functional form of SMAD2 (phosphorylated SMAD2 (pSMAD2)) that represent the activity of TGF $\beta$ receptor signaling has not been evaluated in the GBM patients, we thus analyzed pSMAD2 levels in the resected GBM tissue from 23 patients, and compared with the paired normal brain tissue (NBT) by Western blot. Six specimen were randomly selected and shown as representative images (Fig. 1A). We detected significantly lower pSMAD2 levels in GBM, compared to NBT (Fig. 1B). These data suggest a possibility of involvement of SMAD2 signaling in the pathogenesis of GBM.

Fig. 1. Lower phosphorylated SMAD2 was detected in GBM, compared to paired normal brain tissue in patients. Phosphorylated SMAD2 (pSMAD2) levels in the resected GBM tissue from 23 patients were analyzed, and compared with the paired normal brain tissue (NBT) by Western blot, shown by representative images (A), and by quantification (B). * $<<0.05$.

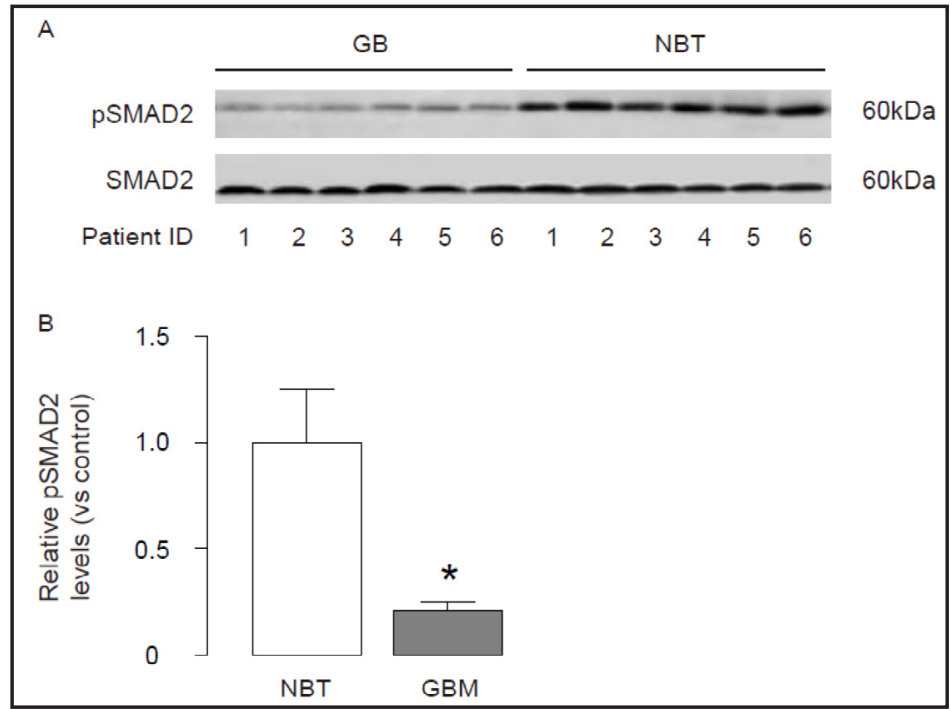


Fig. 2. Preparation of GBM cells with SMAD2 or SMAD3 depletion. SMAD2, or SMAD3 in GBM cells was depleted by shRNAs. GBM cells that were transfected with scrambled sequence (scr) were used as controls. Modification of SMAD2 or SMAD3 levels in A172 cells was confirmed by RT-qPCR (A), and by Western blot (B). $\quad * p<0.05$. NS: non-significant.

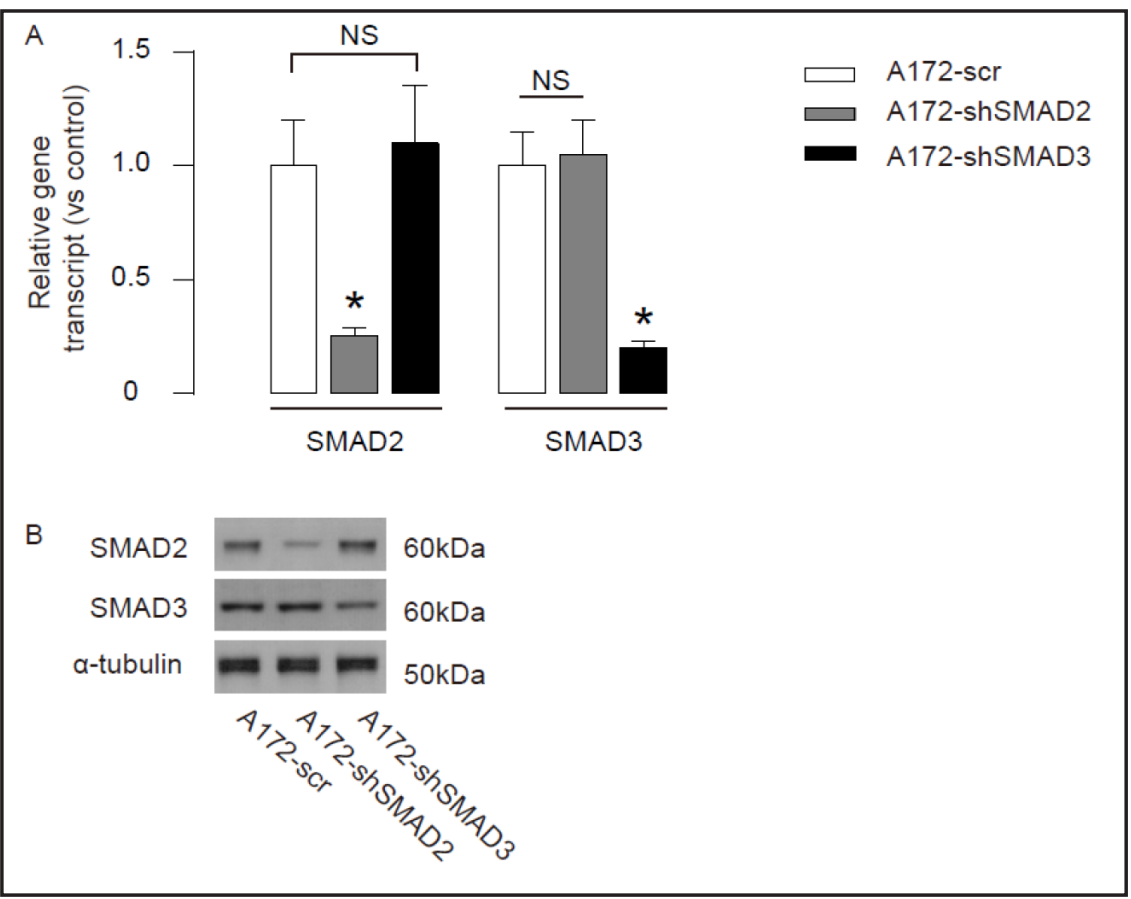

Fig. 3. Depletion of SMAD2, but not SMAD3, significantly abolished the activation of p27 by TGF $\beta 1$. Proteins in GBM cells of either SMAD2 or SMAD3 depletion in responsive to $10 \mathrm{ng} / \mathrm{ml}$ TGF $\beta 1$ were examined by Western blot. A specific TGF $\beta$ receptor inhibitor, SB431542 at a dose of $10 \mu \mathrm{mol} / \mathrm{l}$, was applied with TGF $\beta 1$ to block the signaling at the level of receptor phosphorylation.

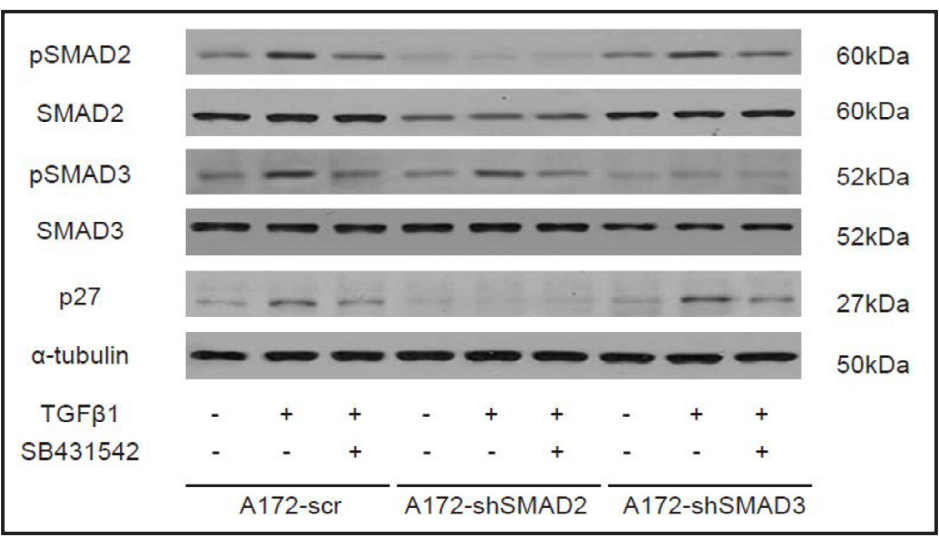

Preparation of GBM cells with SMAD2 or SMAD3 depletions

In order to examine the downstream signaling of activation of TGF $\beta$ receptor, we depleted either SMAD2, or SMAD3 in GBM cells by shRNAs, since phosphorylation of each may transduce the signals from TGF $\beta$ receptor activation. GBM cells that were transfected with scrambled sequence (scr) were used as controls. We examined 4 commonly used GBM cell lines, with different cell origin. Since similar results were achieved from these cell lines, only data from A172 cells were shown. We confirmed the modification of SMAD2 or SMAD3 levels in A172 cells by RT-qPCR (Fig. 2A), and by Western blot (Fig. 2B). Importantly, depletion of SMAD2 did not affect the levels of SMAD3 in A172 cells, and vice versa (Fig. $2 A-B)$. Thus, these cells with SMAD2 or SMAD3 depletion allow us to evaluate the roles of SMAD2 and SMAD3 in the growth of GBM in responsive to TGF $\beta$ receptor activation.

Depletion of SMAD2, but not SMAD3, significantly abolished the growth inhibitory effects of TGFB1 on the growth of GBM cells, possibly through pSMAD2-mediated increases in cell-cycle inhibitor, $p 27$

Then we examined the GBM cells of either SMAD2 or SMAD3 depletion in responsive to TGF $\beta$ receptor activation. TGF $\beta 1$ is potential ligand for TGF $\beta$ receptor and triggers robust receptor phosphorylation and activation. We thus used $10 \mathrm{ng} / \mathrm{ml}$ recombinant TGF $\beta 1$ to 
Fig. 4. Depletion of SMAD2, but not SMAD3, significantly abolished the growth inhibitory effects of TGF $\beta 1$ on the growth of GBM cells. In a MTT assay, pSMAD2 activation, but not pSMAD3 activation, seemed to inhibit the growth of GBM cells in responsive to TGF $\beta 1$ stimulation. ${ }^{*} \mathrm{p}<0.05$. NS: non-significant. Asterisks and "NS" above the columns are statistical comparisons to same cells without any treatments (TGFß1- and SB431542-). Aste-

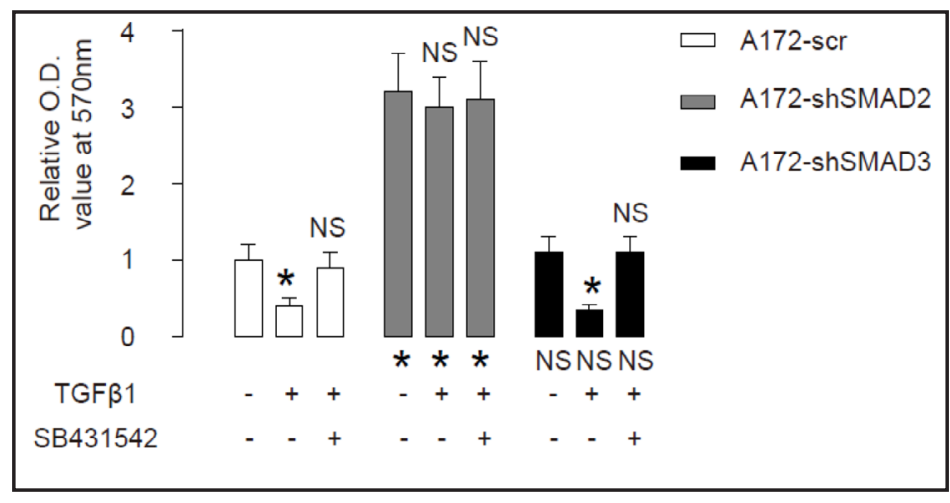
risks and "NS" under the columns are statistical comparisons to A172-scr that received same treatments (TGFß1 and SB431542).

Fig. 5. Schematic of the model.

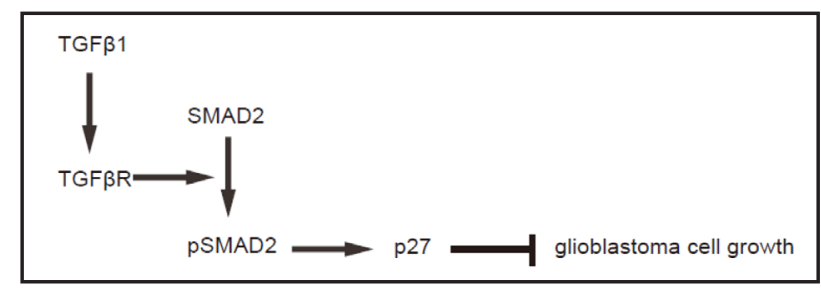

TGF $\beta$ receptor $[32,45,46]$. We also used a specific TGF $\beta$ receptor inhibitor, SB431542 at a dose of $10 \mu \mathrm{mol} / \mathrm{l}$, to block the signaling at the level of receptor phosphorylation.

We found that TGF $\beta 1$ induced significant phosphorylation of both SMAD2 and SMAD3 in A172-scr cells, but only induced significant phosphorylation of SMAD2 in SMAD3depleted A172-shSMAD3 cells, or significant phosphorylation of SMAD3 in SMAD2-depleted A172-shSMAD2 cells (Fig. 3). The inductions of SMAD phosphorylation were completely inhibited by SB431542-mediated blockage of its upstream TGF $\beta$ signaling, the receptor phosphorylation (Fig. 3). Interestingly, depletion of SMAD2, but not SMAD3, significantly abolished the pSMAD2-mediated increases in cell-cycle inhibitor, p27 (Fig. 3) [12, 20, 47-49]. Moreover, in a MTT assay, pSMAD2 activation, but not pSMAD3 activation, seemed to inhibit the growth of GBM cells in responsive to TGF $\beta 1$ stimulation (Fig. 4), which was possibly mediated by p27 upregulation (Fig. 5).

\section{Discussion}

The TGF $\beta$ receptor signaling plays a critical role in the tumorigenesis of various human tumors in that it controls cancer cell growth, invasion and metastasis [6-12, 22-31]. Since growth of GBM accounts for its major malignancy and detrimental effects on patients [1-5], here we aimed to elucidate the precise downstream signaling of an activated TGF $\beta$ receptor signaling on the growth of GBM cells [6-12, 22-31].

Four GBM cell lines that represent different cancer cell type of origin were analyzed, showing similar results within the scope of the current study. Thus, a cell-line dependent possibility was excluded. Since SMAD2 and SMAD3 are the only two direct targets of an activated TGF $\beta$ receptor signaling, we depleted each and checked the effects on the cancer cell growth in responsive to TGF $\beta 1$ stimulation, the effect of which was validated by a receptor phosphorylation inhibitor upstream of SMAD2/3 phosphorylation.

Interestingly, we found that depletion of SMAD2, but not SMAD3, significantly abolished the inhibitory effects of TGFß1 on the growth of GBM cells, possibly through pSMAD2mediated increases in cell-cycle inhibitor, p27. The control of p27 by pSMAD2 has been well-established [12, 20, 47-49]. Since pSMAD2 forms a complex with SMAD4 and then 
translocates into the nucleus to allow its direct binding to DNA to modulate gene expression, e.g. p27, our data suggest that pSMAD2, or nuclear SMAD2, has a potential effect in restraining the growth of GBM. Since p21 is also known to be regulated by SMAD signaling [13-18], we also examined p21 in our study but got negative results. Thus, p27, but p21 is the direct target of SMAD2 signaling in this model. Thus, biological of chemical induction of SMAD2 phosphorylation and nuclear translocation and/or retention may substantially inhibit the growth of GBM, which sheds light on a promising novel therapy.

Our innovative findings that differentiate pSMAD2 from pSMAD3 in the growth of GBM are critical, since SMAD3 signaling has been extensively studied and found mainly related to cell differentiation and transition [6-12, 22-31]. Thus, the effect of TGF $\beta$ receptor signaling may have its effects on cell growth through pSMAD2-mediated regulation of cell-cycle controllers, and on cell migration and invasion through pSMAD3-mediated EMT-related genes. These hypothesis needs to be confirmed in different cancers, and in different models. If proved, it may provide substantially critical information for delicate control of the complex TGF $\beta$ receptor signaling pathway, not only in cancer, but also in other biological researches.

\section{Acknowledgement}

This work was supported by GuiZhou Province Scientific Award for Society Development SY(2012)3118 and GuiZhou Province Natural Scientific Fundation (2013) 2311.

\section{Disclosure Statement}

The authors have declared that no competing interests exist.

\section{References}

1 Schonberg DL, Bao S, Rich JN: Genomics informs glioblastoma biology. Nat Genet 2013;45:1105-1107.

-2 Chen J, Huang Q, Wang F: Inhibition of foxo1 nuclear exclusion prevents metastasis of glioblastoma. Tumour Biol 2014;35:7195-7200.

3 Gong J, Zhu S, Zhang Y, Wang J: Interplay of vegfa and mmp2 regulates invasion of glioblastoma. Tumour Biol 2014;35:11879-11885.

4 Li S, Gao Y, Ma W, Guo W, Zhou G, Cheng T, Liu Y: Egfr signaling-dependent inhibition of glioblastoma growth by ginsenoside rh2. Tumour Biol 2014;35:5593-5598.

5 Wang F, Xiao W, Sun J, Han D, Zhu Y: Mirna-181c inhibits egfr-signaling-dependent mmp9 activation via suppressing akt phosphorylation in glioblastoma. Tumour Biol 2014;35:8653-8658.

6 Massague J: Tgfbeta in cancer. Cell 2008;134:215-230.

7 Shi Y, Massague J: Mechanisms of tgf-beta signaling from cell membrane to the nucleus. Cell 2003;113:685700 .

-8 Kretzschmar M, Massague J: Smads: Mediators and regulators of tgf-beta signaling. Curr Opin Genet Dev 1998;8:103-111.

-9 Massague J, Chen YG: Controlling tgf-beta signaling. Genes Dev 2000;14:627-644.

10 Massague J: Tgfbeta signalling in context. Nat Rev Mol Cell Biol 2012;13:616-630.

11 Xiao X, Wiersch J, El-Gohary Y, Guo P, Prasadan K, Paredes J, Welsh C, Shiota C, Gittes GK: Tgfbeta receptor signaling is essential for inflammation-induced but not beta-cell workload-induced beta-cell proliferation. Diabetes 2013;62:1217-1226.

12 Xiao X, Gaffar I, Guo P, Wiersch J, Fischbach S, Peirish L, Song Z, El-Gohary Y, Prasadan K, Shiota C, Gittes GK: M2 macrophages promote beta-cell proliferation by up-regulation of smad7. Proc Natl Acad Sci U S A 2014;111:E1211-1220.

-13 Liu R, Zhou Z, Huang J, Chen C: Pmepa1 promotes androgen receptor-negative prostate cell proliferation through suppressing the smad3/4-c-myc-p21 cip1 signaling pathway. J Pathol 2011;223:683-694. 


\section{Cellular Physiology Cell Physiol Biochem 2015;35:1756-1763 \begin{tabular}{l|l} 
DOI: 10.1159/000373987 & $\begin{array}{l}\text { O 2015 S. Karger AG, Basel } \\
\text { www.karger.com/cpb }\end{array}$ \\
\hline
\end{tabular}}

Yu/Ran: Nuclear SMAD2 Inhibits Glioblastoma

14 Chuang TD, Guh JY, Chiou SJ, Chen HC, Hung WC, Chuang LY: Sp1 and smad3 are required for high glucoseinduced p21(waf1) gene transcription in llc-pk1 cells. J Cell Biochem 2007;102:1190-1201.

15 Wilkes MC, Mitchell H, Penheiter SG, Dore JJ, Suzuki K, Edens M, Sharma DK, Pagano RE, Leof EB: Transforming growth factor-beta activation of phosphatidylinositol 3-kinase is independent of smad2 and smad3 and regulates fibroblast responses via p21-activated kinase-2. Cancer Res 2005;65:10431-10440.

-16 Charng MJ, Wu CH: Transcriptional activation of p21 by tranilast is mediated via transforming growth factor beta signal pathway. Br J Pharmacol 2006;147:117-124.

17 Pardali K, Kowanetz M, Heldin CH, Moustakas A: Smad pathway-specific transcriptional regulation of the cell cycle inhibitor p21(waf1/cip1). J Cell Physiol 2005;204:260-272.

18 Pardali K, Kurisaki A, Moren A, ten Dijke P, Kardassis D, Moustakas A: Role of smad proteins and transcription factor sp1 in p21(waf1/cip1) regulation by transforming growth factor-beta. J Biol Chem 2000;275:29244-29256.

19 Miles FL, Tung NS, Aguiar AA, Kurtoglu S, Sikes RA: Increased tgf-beta1-mediated suppression of growth and motility in castrate-resistant prostate cancer cells is consistent with smad $2 / 3$ signaling. Prostate 2012;72:1339-1350.

20 Lecanda J, Ganapathy V, D'Aquino-Ardalan C, Evans B, Cadacio C, Ayala A, Gold LI: Tgfbeta prevents proteasomal degradation of the cyclin-dependent kinase inhibitor p27kip1 for cell cycle arrest. Cell Cycle 2009;8:742-756.

21 Baughn LB, Di Liberto M, Niesvizky R, Cho HJ, Jayabalan D, Lane J, Liu F, Chen-Kiang S: Cdk2 phosphorylation of smad 2 disrupts tgf-beta transcriptional regulation in resistant primary bone marrow myeloma cells. J Immunol 2009;182:1810-1817.

22 Anido J, Saez-Borderias A, Gonzalez-Junca A, Rodon L, Folch G, Carmona MA, Prieto-Sanchez RM, Barba I, Martinez-Saez E, Prudkin L, Cuartas I, Raventos C, Martinez-Ricarte F, Poca MA, Garcia-Dorado D, Lahn MM, Yingling JM, Rodon J, Sahuquillo J, Baselga J, Seoane J: Tgf-beta receptor inhibitors target the cd44(high)/ id1(high) glioma-initiating cell population in human glioblastoma. Cancer Cell 2010;18:655-668.

23 Penuelas S, Anido J, Prieto-Sanchez RM, Folch G, Barba I, Cuartas I, Garcia-Dorado D, Poca MA, Sahuquillo J, Baselga J, Seoane J: Tgf-beta increases glioma-initiating cell self-renewal through the induction of lif in human glioblastoma. Cancer Cell 2009;15:315-327.

-24 Strelau J, Schmeer C, Peterziel H, Sackmann T, Herold-Mende C, Steiner H, Weller M, Unsicker K: Expression and putative functions of gdf-15, a member of the tgf-beta superfamily, in human glioma and glioblastoma cell lines. Cancer Lett 2008;270:30-39.

-25 Grzmil M, Morin P, Jr., Lino MM, Merlo A, Frank S, Wang Y, Moncayo G, Hemmings BA: Map kinaseinteracting kinase 1 regulates smad2-dependent tgf-beta signaling pathway in human glioblastoma. Cancer Res 2011;71:2392-2402.

-26 Zhang M, Kleber S, Rohrich M, Timke C, Han N, Tuettenberg J, Martin-Villalba A, Debus J, Peschke P, Wirkner U, Lahn M, Huber PE: Blockade of tgf-beta signaling by the tgfbetar-i kinase inhibitor ly2109761 enhances radiation response and prolongs survival in glioblastoma. Cancer Res 2011;71:7155-7167.

27 Piek E, Westermark U, Kastemar M, Heldin CH, van Zoelen EJ, Nister M, Ten Dijke P: Expression of transforming-growth-factor (tgf)-beta receptors and smad proteins in glioblastoma cell lines with distinct responses to tgf-beta1. Int J Cancer 1999;80:756-763.

-28 Eichhorn PJ, Rodon L, Gonzalez-Junca A, Dirac A, Gili M, Martinez-Saez E, Aura C, Barba I, Peg V, Prat A, Cuartas I, Jimenez J, Garcia-Dorado D, Sahuquillo J, Bernards R, Baselga J, Seoane J: Usp15 stabilizes tgfbeta receptor $\mathrm{i}$ and promotes oncogenesis through the activation of tgf-beta signaling in glioblastoma. Nat Med 2012;18:429-435.

29 Seystahl K, Tritschler I, Szabo E, Tabatabai G, Weller M: Differential regulation of tgf-beta-induced, alk-5-mediated vegf release by smad2/3 versus smad1/5/8 signaling in glioblastoma. Neuro Oncol 2015;17:254-265.

30 Golestaneh N, Mishra B: Tgf-beta, neuronal stem cells and glioblastoma. Oncogene 2005;24:5722-5730.

31 Pen A, Moreno MJ, Durocher Y, Deb-Rinker P, Stanimirovic DB: Glioblastoma-secreted factors induce igfbp7 and angiogenesis by modulating smad-2-dependent tgf-beta signaling. Oncogene 2008;27:6834-6844.

32 Joseph JV, Conroy S, Tomar T, Eggens-Meijer E, Bhat K, Copray S, Walenkamp AM, Boddeke E, Balasubramanyian V, Wagemakers M, den Dunnen WF, Kruyt FA: Tgf-beta is an inducer of zeb1-dependent mesenchymal transdifferentiation in glioblastoma that is associated with tumor invasion. Cell Death Dise 2014;5:e1443. 


\section{Cellular Physiology Cell Physiol Biochem 2015;35:1756-1763 \begin{tabular}{ll|l} 
and Biochemistry Publisned onlIne: Vvarch 23, 2015 & $\begin{array}{l}\text { C) } 2015 \text { S. Karger AG, Basel } \\
\text { www.karger.com/cpb }\end{array}$ \\
\hline
\end{tabular} \\ Yu/Ran: Nuclear SMAD2 Inhibits Glioblastoma}

33 Lv S, Zhang J, Han M, Wang W, Zhang Y, Zhuang D, Shi R, Bian R, Yao C: Nucleolin promotes tgf-beta signaling initiation via tgf-beta receptor i in glioblastoma. J Mol Neurosci 2015;55:1-6.

34 Jiang H, Jin C, Liu J, Hua D, Zhou F, Lou X, Zhao N, Lan Q Huang Q, Yoon JG, Zheng S, Lin B: Next generation sequencing analysis of mirnas: Mir-127-3p inhibits glioblastoma proliferation and activates tgf-beta signaling by targeting ski. OMICS 2014;18:196-206.

-35 Wesolowska A, Kwiatkowska A, Slomnicki L, Dembinski M, Master A, Sliwa M, Franciszkiewicz K, Chouaib S, Kaminska B: Microglia-derived tgf-beta as an important regulator of glioblastoma invasion--an inhibition of tgf-beta-dependent effects by shrna against human tgf-beta type ii receptor. Oncogene 2008;27:918-930.

-36 Pan JJ, Chang WJ, Barone TA, Plunkett RJ, Ostrow PT, Greenberg SJ: Increased expression of tgf-beta1 reduces tumor growth of human $\mathrm{u}-87$ glioblastoma cells in vivo. Cancer Immunol Immunother 2006;55:918-927.

37 Leitlein J, Aulwurm S, Waltereit R, Naumann U, Wagenknecht B, Garten W, Weller M, Platten M: Processing of immunosuppressive pro-tgf-beta 1,2 by human glioblastoma cells involves cytoplasmic and secreted furin-like proteases. J Immunol 2001;166:7238-7243.

-38 Fujiwara T, Mukhopadhyay T, Cai DW, Morris DK, Roth JA, Grimm EA: Retroviral-mediated transduction of p53 gene increases tgf-beta expression in a human glioblastoma cell line. Int J Cancer 1994;56:834-839.

-39 Giard DJ, Aaronson SA, Todaro GJ, Arnstein P, Kersey JH, Dosik H, Parks WP: In vitro cultivation of human tumors: Establishment of cell lines derived from a series of solid tumors. J Natl Cancer Inst 1973;51:14171423.

40 Clark MJ, Homer N, O'Connor BD, Chen Z, Eskin A, Lee H, Merriman B, Nelson SF: U87mg decoded: The genomic sequence of a cytogenetically aberrant human cancer cell line. PLoS Genet 2010;6:e1000832.

41 Ganzinger M, He S, Breuhahn K, Knaup P: On the ontology based representation of cell lines. PLoS One 2012;7:e48584.

-42 Callahan JF, Burgess JL, Fornwald JA, Gaster LM, Harling JD, Harrington FP, Heer J, Kwon C, Lehr R, Mathur A, Olson BA, Weinstock J, Laping NJ: Identification of novel inhibitors of the transforming growth factor beta1 (tgf-beta1) type 1 receptor (alk5). J Med Chem 2002;45:999-1001.

43 Inman GJ, Nicolas FJ, Callahan JF, Harling JD, Gaster LM, Reith AD, Laping NJ, Hill CS: Sb-431542 is a potent and specific inhibitor of transforming growth factor-beta superfamily type i activin receptor-like kinase (alk) receptors alk4, alk5, and alk7. Mol Pharmacol 2002;62:65-74.

-44 Laping NJ, Grygielko E, Mathur A, Butter S, Bomberger J, Tweed C, Martin W, Fornwald J, Lehr R, Harling J, Gaster L, Callahan JF, Olson BA: Inhibition of transforming growth factor (tgf)-beta1-induced extracellular matrix with a novel inhibitor of the tgf-beta type i receptor kinase activity: Sb-431542. Mol Pharmacol 2002;62:58-64.

45 Huang S, Liao Q, Li L, Xin D: Pttg1 inhibits smad3 in prostate cancer cells to promote their proliferation. Tumour Biol 2014;35:6265-6270.

46 Yu X, Jiang Y, Wei W, Cong P, Ding Y, Xiang L, Wu K: Androgen receptor signaling regulates growth of glioblastoma multiforme in men. Tumour Biol 2014.

47 Kfir S, Ehrlich M, Goldshmid A, Liu X, Kloog Y, Henis YI: Pathway- and expression level-dependent effects of oncogenic n-ras: P27(kip1) mislocalization by the ral-gef pathway and erk-mediated interference with smad signaling. Mol Cell Biol 2005;25:8239-8250.

48 Birchenall-Roberts MC, Fu T, Bang OS, Dambach M, Resau JH, Sadowski CL, Bertolette DC, Lee HJ, Kim SJ, Ruscetti FW: Tuberous sclerosis complex 2 gene product interacts with human smad proteins. A molecular link of two tumor suppressor pathways. J Biol Chem 2004;279:25605-25613.

-49 Liu X, Sun Y, Ehrlich M, Lu T, Kloog Y, Weinberg RA, Lodish HF, Henis YI: Disruption of tgf-beta growth inhibition by oncogenic ras is linked to p27kip1 mislocalization. Oncogene 2000;19:5926-5935. 